\title{
Erratum to: 'Complete genome sequence of Roseophage vB_DshP-R1, which infects Dinoroseobacter shibae DFL12'
}

Jianda Ji, Rui Zhang ${ }^{*}$ and Nianzhi Jiao*

Unfortunately, the original version of this article [1] contained an error. The citation details was included incorrectly as 9:31. The correct citation is 10:6.

Received: 17 August 2015 Accepted: 17 August 2015

Published online: 24 September 2015

\section{Reference}

1. Ji J, Zhang R, Jiao N. Complete genome sequence of Roseophage vB_DshP-R1, which infects Dinoroseobacter shibae DFL12. Standards in Genomic Sciences. 2015;10:6.

* Correspondence: ruizhang@xmu.edu.cn; jiao@xmu.edu.cn

Submit your next manuscript to BioMed Central and take full advantage of:

- Convenient online submission

- Thorough peer review

- No space constraints or color figure charges

- Immediate publication on acceptance

- Inclusion in PubMed, CAS, Scopus and Google Scholar

- Research which is freely available for redistribution 